\title{
Re-writing knowledge, re-design textbooks: auto-production of contents in the classroom
}

\section{Reescrever o conhecimento, redesenhar o livro didático: a autoprodução de conteúdo em sala de aula}

\section{Riscrivere la conoscenza, riprogettare il libro di testo: la classe e l'autoproduzione dei contenuti}

\author{
Alessandra Anichini* \\ Laura Parigi*
}

\begin{abstract}
This contribution is a report of a qualitative research carried out within the Avanguardie Educative project aimed at describing and analyzing the experience of a group of Italian teachers in relation to the practice of textbook and digital resources auto-production. The research, conducted with some schools involved in an experimentation process of the alternative adoption of the textbook, has allowed us to start an in-depth reflection on the motivations that induce teachers to opt for this choice, in the direction of a rereading the relationship between curriculum, national indications and teaching autonomy, with particular attention to the student considered as an active subject of his / her training.
\end{abstract}

Keywords: Textbook. Didactical digital content. Auto-produced textbook. Learning practice.

* Istituto Nazionale Documentazione, Innovazione e Ricerca Educativa (INDIRE). Firenze, Italia. E-mail: a.anichini@indire.it.https://orcid.org/0000-0002-3319-1689.E-mail: 1.parigi@indire. it. https://orcid.org/0000-0003-2801-5928. 


\section{RESUMO}

$\mathrm{O}$ artigo relata resultados de pesquisa qualitativa realizada no âmbito do projeto Avanguardie Educative, com o objetivo de descrever e analisar a experiência de um grupo de professores italianos em relação à prática de autoprodução de livros didáticos ou conteúdos educacionais digitais. A pesquisa, realizada com escolas envolvidas em um processo de experiência de adoção alternativa ao livro didático, permitiu discutir as motivações que conduzem os professores a optarem por essa escolha, no sentido de uma releitura das relações entre currículo, indicações ministeriais e autonomia de ensino, com especial atenção ao aluno considerado sujeito ativo de sua formação.

Palavras-chave: Livros didáticos. Conteúdos didáticos digitais. Produção de livros pelos professores. Prática educacional.

\section{SINTESI}

Il presente contributo è il resoconto di una ricerca qualitativa effettuata all'interno del progetto Avanguardie Educative e volta a descrivere ed analizzare il vissuto di un gruppo di docenti italiani in relazione alla pratica di autoproduzione dei libri di testo o dei contenuti didattici digitali. La ricerca, condotta con alcune scuole coinvolte in un percorso di sperimentazione dell'adozione alternativa del libro di testo, ha consentito di avviare una riflessione approfondita sulle motivazioni che inducono i docenti ad optare per questa scelta, nella direzione di una rilettura del rapporto tra curriculum, indicazioni nazionali e autonomia di insegnamento, con un'attenzione allo studente considerato soggetto attivo del proprio percorso formativo.

Parole chiave: Libro di testo. Contenuto didattico digitale. Auto-produzione dei libri di testo. Pratica Educativa.

"Knowledge exists only in invention, in re-invention, in the restless, impatient, permanent search that men do in the world, with the world and with others" (Freire, The Pedagogy of the Oppressed)

\section{Introduction}

Since 2014, a series of initiatives supported by INDIRE, the Italian National Institute for Documentation, Innovation and Educational Research, have 
been oriented to describe student's study practices, especially regarding the use of textbooks (Anichini, Chipa, Parigi, 2017). The research has been carried out within the Avanguardie Educative community, that involves a large number of Italian schools engaged in the renewal of teaching practices relating to different aspects, from time and space organization, up to the use of specific tools or methodologies (Laici, Orlandini, 2016).

Textbooks and digital content have been a topic of great interest in our country (Roncaglia, 2016), also in consideration of the recent legal indications of the Italian Ministry of Education (Law 128/2013 - DM 781/2013). In fact, since 2013 the adoption of textbook is no longer mandatory. Teachers can choose from a series of options that tend to integrate the traditional volumes with additional contents that can be part of the adopted books, or, if necessary, can be chosen from the catalogue of different publishing houses, acquired on the Net or even auto-produced. Necessary condition: manuals and the integrative didactic contents are partly or integrally digital. Furthermore, the replacement of a standardized national curriculum with National Guidelines (Indicazioni Nazionali), that identify core content and learning goals, letting schools free to design their own curriculum, has contributed to questioning the relationship with the textbooks that, for years, have been guaranteed an accredited a common path, which actually followed the ministerial norm on the content to be treated for each subject taught, also indicating the precise time scan. The textbook, that still represents for many teachers but also for students' families a sort of "curriculum de facto", clashes today against the National Guidelines, which promote flexible, adequate training courses in particular contexts, while respecting some fundamental contents for each of the disciplines taught. As an instrument of undisputed usefulness for everyday teaching, the textbook is still today one of the key objects of the school (Braga Garcia, 2015) and it is the focus of a reflection that more generally involves the theme of scholastic innovation and of profound transformation taking place, due to the advent of new information technologies in the schools (Moeglin, 2010). The inadequacy of the textbook, denounced by many Avanguardie teachers who criticize its inadequacy and lack of flexibility, contrasts with its image as an indispensable tool, for guaranteeing the quality and reliability of the contents, as an authoritative source of information for students (Anichini, Chipa, Parigi, 2016).

Beyond the debate still ongoing, the present research aims above all at studying the role of the textbook in student educational training, recovering its fundamental functions (Choppin, 2008) and reinterpreting them in the light of the new possibilities offered by information and communication technologies (Anichini, 2014). The main objective is to promote a reflection on the value of a study activity much different from the mnemonic repetition of information or 
concepts and rather interpreted as a re-elaboration of knowledge, as the ability to operate those connections that allow to overcome the barriers between the different subjects, in the name of an authentic and complex knowledge.

The analysis of the activity of schools that are involved in the auto-production of textbooks and digital educational content (Bruillard, Villemonteix, 2011; Castiello, 2015) is therefore above all an opportunity to reflect on the profound meaning of the word "study" on the relationship established between the subject curriculum and an "emergent curriculum" that is enriched by the thoughts of the students and represents the possibility of connecting the fundamental disciplinary knowledge with the questions emerging from the reality of the school contexts (Braga Garcia, Schmidt, 2015; Rodríguez Rodríguez, Garcia Garcia, 2015).

\section{Scenario}

"The world is not something to be spoken of with false words, but the mediator of the subjects of education, the place of incidence of the transforming action of men, from which their humanization results" (Freire, 2011, p. 76). In the Pedagogy of the Oppressed, Freire contrasts a "depository" conception of education, typical of an immobile and oppressive culture, and a "problematizing" one, an indispensable agent for the "practice of freedom", capable of bringing out consciences and favoring their "critical insertion in reality". The problematizing practice, "gnoseological situation" par excellence, eliminates the distance that traditional didactical models seem to inevitably establish: between teacher and student, and, closely connected, between student and the world.

The world is the third element of the relationship capable of filling the separation between teacher and learner, object of dialogue, necessary mediator on which all the transforming force of education is grafted. What is established between teacher and learner is always, in fact, a "dialogue on", a reflection that originates from and focuses on specific content, in connection with a fragment of that world, that reality of which the subjects are an active part. Starting from a comparison on and with the object/world, liberating education generates a process of continuous knowledge construction, which is not limited to the acquisition of notions and concepts, but interacts with them in a movement of re-elaboration and unceasing creation. The significance of this third element of formative communication (the content of the dialogue, the reality underlying it) represents the heart of the Freire pedagogy that we have chosen as a paradigm for these pages, in which the textbook is intended as an "object mediator" of 
the educational relationship, a key artifact within it, as well as tangible representation of a possible compromise between institutional curriculum, "emergent curriculum" and "contextual curriculum".

The relationship between the school and the world was also at the center of the reflections of Celestin Freinet:

In an age in which the mass of human knowledge exceeds the possibility of the most gifted individuals, it is essential to prepare children to reflect, to seek, to read up, to choose, to prepare the bases of the answers to the problems, not only in an intellectual but also technical and social manner that life poses and offers them. The school is bound to arouse and cultivate this constructive attitude, which is activated only through experience (Freinet, 2002, p. 76).

Wrote Vence's teacher in a 1937 article, later revived in 1964, dedicated to the textbook and its inadequacy in a school that must help students learn to "act and create" rather than "listen and obey". Freinet proposed typography in the classroom as a technique capable of sustaining students' interest and favoured the awareness of an immediate usability of what is learned, of direct link between school and the world outside. The didactic suggestion offered to colleagues is replacing the study of "three, five, or ten so often indigestible summary books" with a work that allows each student to learn from thousands of books, but also from other sources: records, interviews and above all from systematic observation and analysis of reality.

In the following years, typography in the classroom becomes a technique practiced by many teachers throughout Europe. In Italy, the Educational Cooperation Movement (MCE) supports it by promoting, in primary schools, the auto-production of the textbook. Many classrooms, in fact, replaced textbooks for reading and for historical, geographical and scientific subjects with a series of volumes to create the class library and, with other text to use as resources for drafting of auto-produced books. As in Italy the purchase of primary school textbooks is founded by the government, schools converted funding to create these classroom libraries.

In these classrooms, the curricular topics are discussed and studied in depth by documenting texts of various kinds, carrying out the curriculum contextualization, which consists in identifying in the students' experience the links with the themes treated in the books and vice versa, considering the particular context part of a wider reality, beyond the territorial boundaries. The 
chosen themes arise from the reflection conducted in the classroom, from the observation of family life, of the country, of the cities, of the socio-economic contexts of which the school is part, but attentive to the broad and generalizing context of the experiences.

"A book that offers all the children of a class the same readings, the same images, would not make sense not only in the context of avant-garde education, but even according to the programs" wrote Aldo Pettini, Bruno Ciari, Mario Lodi, Luisa Tosi, Ines Casanova, Renata Dellacasa, Daria Ridolfi at the end of the Sixties (Pettini et al., 1969, p. 1), aware that the idea of a curriculum as a standardized programme of study "program" had to be reread and reduced in specific school situations. A few years later, Mario Lodi, a primary school teacher and one of the main voices of the MCE pedagogical research the postwar years, also wrote against the generality of textbooks that did not take into account the life contexts of students (Lodi, 1977). This idea gradually takes root elsewhere, in lesser known situations and slowly it becomes the ordinary patrimony of hundreds of teachers, not necessarily linked to the MCE, but who have taken the suggestion of this movement.

"Alternative adoption" became a possibility supported by Law 517 in 1977, due to a reform which brought some substantial innovations in Italian schools, including full-time schools. Subsequently the possibility for the primary school to opt for alternative adoption will be reaffirmed by the Legislative Decree of April 16th 1994, n. 297 - Consolidated Text of the provisions in force concerning education, relating to schools of all levels:

For elementary school classes, which carry out experiments pursuant to articles 277 and 278, if alternative forms of use of the book are provided for text, the use of the sum equivalent to the cost of the textbook for the purchase by the club council of other library material is allowed, according to the bibliographical indications contained in the experimentation project (Art. 156, comma 2).

Articles 277 (Methodological and didactic experimentation) and 278 (Experimentation and innovation of legal systems and structures) of the Consolidated Text will then be repealed by the Regulation on autonomy and replaced by the indications contained in Article 6 and Article 4 of Presidential Decree 275/99: "The choice, adoption and use of teaching methods and tools, including textbooks, are consistent with the Educational offer plan (School curriculum)" (Law 517). 
The primary school is the privileged ground in which this kind of innovation is grafted and we have to wait a few decades for involving also the secondary school. For years, many primary school classes have produced their history and geography texts in which the specificity of the paths was linked in a particular way to context elements: local history, insights into the territory on geographical or economic aspects, anthropological sections with interviews and collection of local traditions. These are still not very widespread experiences and despite the possibilities granted by law, the adoption of the textbook continues to be the dominant solution in our country.

However, after the recent legislative innovations, a new phase has opened in Italy. The textbook certainly continues to be a central object for teaching, a very useful tool for teachers and students, a link between school and family, the first point of reference for the national curriculum, guarantor of a defined training course (Choppin, 2003), but its role is re-discussed in the light of a renewal of teaching methods and strategies. Its assertive, static nature, as an object designed to "transfer" contents of knowledge by depositing them in the minds of students condemned to the mnemonic repetition of information and concepts, appears to be most adverse to the generative logic of knowledge. The textbook, as traditionally understood, is a function of a conservative conception of knowledge (Eco, Bonazzi, 1972) that is badly combined with the pedagogical assumptions underlying some widespread teaching practices. Furthermore, the new focus on a curricula revision, which, according to the National Guidelines, allows the schools to choose curricular content according to the specific situation, constitutes a push to integrate the contents of the manuals with specific insights.

The auto-production of textbooks and digital content is also linked to a specific idea of the school as a laboratory, according to the Dewey principles of the active school, an operating space in which "objects" are created. Not a "school of doing" where a practice based on procedures dominates, completely mirroring the school of notions, but a school of projects and planning, according to the indications of William Kilpatrick. The school activity is oriented by a "work plan" shared by teachers and students, whose implementation requires the acquisition of a particular kind of knowledge and skills. The planning that inspires this kind of activity is far from the procedural logic that mortifies individual creativity; it is inspired, rather, by the indications of Bruno Munari, a leading designer in the culture of the Sixties/Eighties, only indirectly involved in pedagogical research although very influential in the school of those years. His reflections on the theme of design and planning are well summarized in the volume Da cosa nasce cosa, in which the author tries to solve the dichotomy between the idea of project and that of creativity. In Munari's theoretical perspective, the concept of design is closely linked to creativity: creativity and 
design are an inseparable pair, from the moment in which the former is not to be considered a spontaneous and innate phenomenon, free from constraints, but is deeply linked to precise contexts and destined to feed through the comparison with a norm, a technique. "Creativity does not mean improvisation without method: in this way only confusion is created and young people are deluded in feeling themselves free and independent artists" (Munari, 2003, p. 17). Creativity is stimulated by problematic situations and is the result of a conscious research that involves study and discipline:

Creativity is a productive capacity where imagination and reason are linked so that the result obtained is always practically achievable. [...] With creativity, the designer, after analyzing the problem to be solved, looks for a synthesis between the data obtained from the various components to find an optimal new solution, where every single solution is merged with the others according to the way that is considered the best to reach a total balance (Munari, 2004, p. 22-23).

Knowledge plays a key role in this process: "The basic problem, therefore, for the development of fantasy, is the increase of knowledge, to allow a greater number of possible relationships between a greater number of data" (Munari, 2004, p. 35). Planning is synonymous with discipline, orientation, knowledge, which are also the basis of the creative process, a reflection that has repercussions on school work in general and in the relationship with digital environments in particular. It helps to disavow, in some way, a belief in vogue in the schools of our years that prefigures students much more prepared than their teachers in comparison with the new digital tools, in the name of their supposed "digital nativity".

This activity of auto-production of study contents is configured as an activity of "re-writing", producing "conceptual artifacts", according to the definition given by Carl Bereiter. In an article written in 2002, the author argues for the need to help students make forays into the territories of the "Third World" of Popperian memory, not just as visitors but as active participants, in order to promote their leanings for conceptualization and formulation of ideas, after and while having massively attended the First World (of things) and the Second World (of thoughts and feelings). The explanation they produce are conceptual artifacts, and they can work collaboratively to improve them. Distancing himself from a limiting interpretation of pedagogical constructivism, which interprets the "construction" as an almost spontaneous act, performed by the learner, perhaps 
within training courses characterized by "learning by doing approach" and by rigid and stereotyped procedural models, (Bereiter, 2002) Bereiter proposes his idea of "re-writing" as an ability to deal with concepts and ideas, passing through the acquisition of knowledge, its comparison and its verification, its representation in legible forms for the reference culture.

The idea of an emerging curriculum, supported by Gert Biesta (a curriculum whose meaning is not acquired once and for all) is linked to this "re-writing" activity which is fundamental for student learning, but "is continuously made and remade through engagement with our world" (Osberg, Biesta, 2008, p. 2).

\section{The research}

In this scenario we placed this research that is part of the activities of Avanguardie Educative, the project promoted by INDIRE in 2014, which continues working closely with an ever-increasing number of Italian schools (to date 800 schools of different orders and degrees), engaged in a process of profound renewal of teaching and organization of the school (Cochran-Smith, Feiman-Nemser, McIntyre, Demers, 2008).

In the research carried out by Avanguardie Educative and in particular in a part of it that concerns the textbooks and supplementary educational content, the ways in which some of the most innovative schools in the country are approaching the process of auto-production of manuals have already been studied (Anichini, Chipa, Parigi, 2016). The activities carried out were aimed at studying and describing the most innovative didactic practices, which enable students to be active and involved in a process of real knowledge building. The description of the practices implemented by the schools, merged into a Guidelines document for implementation addressed to colleagues from other schools, was accompanied by a reflection on the practices themselves, supported by researchers together with teachers of the schools participating in the Avanguardie movement (Anichini, Bucciarelli, Chipa, Morani, Parigi, Taddeo, 2016). This is a qualitative research, which aimed to study in depth a series of topics during the first phase of the work. The aim is to carry out study on the practice of auto-production by listening to the voice of teachers involved in the project, with the conviction that the transformation of teaching is linked first of all to their idea of school, to their perception of the role of the teacher and of the tools used daily, starting out with the textbook (Choppin, 2003). 
The research in question, therefore focuses on the motivations that induced teachers of every order and degree to undertake the alternative adoption of textbooks and the auto-production of digital educational content in their classes, developing with them a reflection on the choices adopted and the principles that guide their work, with particular attention to the relationship that is established between National Guidelines, factual curriculum, and contextual curriculum.

\section{Methodology}

During the year 2017/18 the research involved a group of teachers belonging to 11 schools of the national territory, of different orders and degrees, all engaged in auto-production of digital educational content. The work carried out with the 22 teachers was aimed at identifying the reasons that led to implementing innovative methods in relation to the adoption and use of textbooks. The teachers took part in a focus group organized as a SWOT analysis on the pros and cons of auto-production of textbooks and digital educational content. In particular, the teachers were asked a single question: What are the strengths, weaknesses, opportunities and risks of self-production of digital educational content?

Subsequently individual interviews were carried out to investigate some elements that emerged during the focus group and also to gather further information. The semi-structured interview was divided into 3 sections:

- The first, the Tale of practice, was intended to describe the practice of producing a CDD within the class; the teachers were asked to identify one of the assignments carried out and to describe it in terms of content, specifying the type of work required ("What kind of work, individual or group, were teachers required to discuss? How had the content been chosen, whether by the teacher, by the pupils or together. How were the topics and their organization chosen?"). Finally, they were asked to recount the writing process, with reference to the planning and realization phases of the product and student participation.

- The second, Reflections on the curriculum, was aimed at defining the relationship of this type of activity with the disciplinary curriculum; the questions investigated concerned all the teachers' work and their reflection: "How does the didactic content connect with the National Guidelines / Guidelines for grade II secondary school?". We asked the teachers to talk about the methods and teaching techniques implemented, as well as to describe the type of evaluation used, a theme that 
is always central in the observations of the teachers called to express an opinion on the work of the students.

- The third, The Role of the Students, was aimed at describing the behaviour of the students, with an attempt at defining the following: "How was the activity received by the students? What were the positive effects? What kind of difficulties did the students encounter? What were the difficulties you encountered as a teacher?"

The textual corpus collected was subjected to analysis according to the content analysis techniques. Content analysis was conducted with a hermeneutical approach. Each answer was considered as a unit of analysis: category formation was inductive with the objective to elaborate a reduction of the most recurring elements emerging form the corpus (Mayring, 2014).

\section{Results}

\section{Professional reasons}

From the analysis of the discussion conducted and from the teachers' responses, issues that belong to the motivational sphere of the teachers themselves and to their professional life, clearly emerge. Auto-production is perceived, in fact, as a practice of belonging to the group of "innovative" teachers, a sort of professional pride. It is linked to a widespread use of digital technology, considered to be the triggering element of the change implemented. The conviction of this choices as the right one is very strong, even if we note the belief that the organization does not support this type of experience, carried out almost as a personal pioneering activity, by the single teacher or by the single school.

All the participants are convinced that they are dealing with a new methodology, which profoundly changes the way school activities are conducted; a methodology that must be learned, especially if it is a question of completely replacing the textbook with auto-produced materials, such as in the case of schools belonging to the network of Books in progress. Teachers point out the difficulty of spreading the practice among colleagues ("We believed that the practice of $C D D$ would grow faster and instead it goes slowly, even if, when it is known, it explodes because the teachers are happy to enter into a methodology without the use of paper"). Difficulties are attributed to the colleagues' attitude to resist towards innovation in general ("there are teachers who are more accustomed to innovation and even those who are more opposed") and especially to the lack of adequate training paths, to the lack of the necessary infrastructures, including a good Internet connection. A further difficulty emerging from 
the analysis concerns the storage of the produced materials, their preservation in dedicated digital environments, which are always under the responsibility of the individual teacher, or sometimes, of the single school. Teachers would like to have institutional archives available to all schools where resources are readily available and reusable.

\section{Educational reasons}

Teachers reveal some difficulties in clearly expressing extrinsic motivation for the practice of auto-production. In the final phase of the focus, the following question emerged explicitly: "I was wondering: why do I do this? ... I gave myself this answer, I don't know if it is linked to the subjects because it allows me to use a plurality of languages for which... it allows me to be redundant, it allows me to meet all learning styles... ". The theme of learning styles occurs in numerous interventions, as well as the conviction that the plurality of codes and languages of the digital texts is useful for operating didactic differentiation.

Digital didactic content, because of its multimedia nature, can contribute to supporting different learning styles and can guarantee respect for the variety of students' levels present in the classes. In fact, the problem of the heterogeneity of classes, the differences between ways of learning and cultural tools of students strongly emerges. In this sense the textbook produced by the publisher is seen as a limit, as a uniform instrument, incapable of intercepting diversity, except in specific cases, insufficient in proposing an educational differentiation.

Teachers' reflection focuses on the role of guarantor of the program that is still erroneously attributed to the textbook: "Everything starts from the need to change curricula (...) in schools teachers have never understood that there are no longer any standardized curricula". The textbook is represented as a rigid tool, incapable of intercepting themes emerging from the class or the local context ("For example, even the geography book becomes very little useful (...) I am the one who selects the countries based on the course of my class. If there is no India's information and I want to teach about India ... really we need so much content that we can freely choose what we want ... this fluid text we are talking about ... is not fluid yet and these multimedia insights are just right, just ... poor."

From the voice of the teachers we get that the textbooks usually used have the typical approach, characterized by a presentation of synthetic contents, not accurate insights, individual exercises. Auto-production is instead seen as an opportunity for developing "libraries of texts" - often created in digital online platforms which are more functional to the teaching that teachers identify as "active".

Some teachers have represented auto-production of textbooks or digital contents as an "educational device" to develop segments of the "local curricu- 
lum". Others converge on the idea that auto-production is above all a work of reflection, a sort of "metacognitive writing", individual or cooperative, which should constantly accompany active teaching.

The teachers who have recounted this function often equip themselves with completinged tools as (rubrics, work organization processes). This practice seems to produce a real didactic technique that we could approach with a sort of reflective documentation (otherwise definable as a learning diary, a learning story, a path file). "For the students of secondary school classes and for the most part of the primary which in large part have always worked as if on an island, in a laboratory. We reduced frontal lesson, it is done at the beginning of a lesson, at the beginning of a learning unit to introduce... 80 per cent of the school works this way, for all disciplines. At the end of a learning unit, of a topic the children produce, they produce collaboratively. When we talk about the product, for example it can be the authentic task at the end of the learning unit, it is a job that can take them even a week or two, it can take up to three weeks to do it collaboratively and can consist of a video, where they also use the images created by themselves and music, even for a minimum length project, basic, or even a simple Power Point presentation... or a comic.... Then we unofficially have an evaluation column to... establish what the educational content must have, and we will be setting out some broad indicators".

\section{Digital creativity}

Technology is one of the main focus of teachers' reflection. They like to recount their work practices, their solutions for technological implementation. This need has led the group to rethink the very definition of digital educational content. Much has been thought about the formal characteristics of digital platforms, even recovering categories such as "manipulability", "replicability": "What is the great novelty of digital? It is that I can find it everywhere, while for carpentry I have to go to a suitable place, a LIM (White Interactive Board) and two computers and we are ready to go ... the digital tools I have at my disposal. If I have to do a brochure, I do it in broad terms following my purpose ... on paper, but when I go to do it with the computer ... if I'm wrong it's not a tragedy, I take a photo and put another one on. While with paper and hands it takes a little more time... . the digital product gives more possibilities and provides something else: it eliminates the terror of mistake, especially to the younger ones....". 
According to an idea of a school conceived as a place for the construction of knowledge, the textbook is rethought and seen in its essence to take on characteristics that are suitable for promoting critical and constructive attitudes in students and teachers, an approach to knowledge that is research-active (Anichini, 2015). According to teachers' opinion it is a "master object" capable of representing the aggregating center of the teaching activity; not a mere deposit of contents to be acquired, to be "memorized", but a malleable and open object, susceptible by its nature of transformation, starting point and destination of significant learning paths. It is configured as a work trace, which indicates possible itineraries and opens up to additions and re-writings, including in-depth analysis or removal. The textbook thus understood is proposed as a sort of map of disciplinary knowledge, which can and must be accompanied by personalized analysis as well as enriched with a series of supplementary contents.

Such a book may indeed be the product supplied by a school publishing house, but only in the guise of a tool of integration, of openness, that is to say that it presupposes an "authorial completion" by teachers and students. It can also be auto-produced by the schools themselves, that is, transformed into the tangible result of the teaching activity, a representation of the learning processes carried out by a class group, within a limited and defined subject framework, in compliance with themes and interests that "emerge" from the direct comparison with experience.

Finally, students, while they are writing their own textbook can establish a bridge between experience and culture (between true and certain, as Gramsci would have said), to fill that distance which is often the product of a bad school. This activity means refining a method that is properly "research" and allow to establish a contact with technical skills, to penetrate more deeply into the logic of cultural communication, fully understand the mechanisms of the circulation of ideas, and reflect on the effectiveness of their formulation. It means to review the curriculum by making a close connection between contextual themes and general themes, according to what is certainly one of the emergencies of today's society.

\section{Conclusions}

The present research is part of an ongoing process. Indeed, the collaboration between research and school, which characterizes the movement of Avanguardie Educative, continues. This is a process that, taking as a reference 
the phenomenological approach to research (Mortari, 2010), mutually enriches theory and educational practice. Within a broader research project, which includes a series of phases, this part of the work was primarily used to investigate the significance that innovative auto-production practices acquire for teachers who implement them with their students. The motivations that lead teachers to a choice, certainly for them often tiring, which sometimes even puts them in conflict with their colleagues, basically lies in the willing to try practices that can improve learning methods, to be able to better involve students and to intercept their individuality, also identifying a closer relationship between the reality in which they live and the subject themes treated at school: a reconnection between life and knowledge.

For many teachers this means recovering the suggestions of a kind of school that was very important in our own as in other European countries, but which, over the years, has ended up losing its propulsive thrust slipping into a custom that is often little reflected: a recovery of a kind of teaching very present in the eighties of the last century, especially in primary school, inspired by great masters such as Mario Lodi and Bruno Ciari and that consisted of laboratories and activity connected with the surrounding reality. This kind of school has given way, in recent decades, to a kind of "lycealization" of lower school orders, with a substantial recovery of the explanation-exercise-verification model, which bases much of its effectiveness on the punctual study of the textbook. These teachers often have a primary school experience behind them and they re-launch practices already implemented even before the advent of digital. For others, above all belonging to the first and second grade secondary school, the use of self-production is rather linked to the bet on digital as a strategy to innovate teaching and to involve students more deeply in their training: the production of digital educational content is based above all on that adjective "digital" which allows to review school activities and also to better approach the habits of young people. These are motivations of a different order, which deserve to be studied in depth and that give us back the idea of a variegated identity of "innovative teachers". The elements of convergence (and there are) are undoubtedly linked to the common idea of wanting to change the school and to do it in the direction of a regained centrality of the student, as a first element for a good school. In this sense, the auto-production of textbooks and digital educational content can also represent an important opportunity for reflection, useful for reconnecting the different positions and establishing a closer bridge between the recovery of tradition and the future. 


\section{REFERENCES}

Anichini, A. (2014). Digital writing. Nel laboratorio di scrittura. Rimini: Maggioli Editore.

Anichini, A. (2015). Riscritture digitali e libri di testo.Form@re-Open Journal per la formazione in rete, 15(1), 73-86.

Anichini, A., Chipa, S., Parigi, L. (2016). Auto-produced Textbooks: Different Approaches From The Analysis Of The Experience Of Innovative Italian Schools. EDULEARN16 Proceedings, pp. 5029-5036.

Anichini, A., Chipa, S., Parigi, L. (2017). Between tradition and innovation: the use of textbooks and didactic digital contents in classrooms. Relatec: Revista Latinoamericana de Tecnología Educativa, 16(2), 97-110.

Anichini, A., Bucciarelli, I., Chipa, S., Morani, R., Parigi, L., Taddeo, G. et al. (a cura di), (2016). Avanguardie educative. Linee guida per l'implementazione dell'idea "Integrazione CDD/Libri di testo», Indire, Firenze.

Bereiter, C. (2002). Artifacts, Canons, and the Progress of Pedagogy: a Response to Contributors. In: Smith, B. Liberal Education in a Knowledge Society, Chicago: Open Court.

Braga Garcia, T. M. (2015). Textbook production from a local, national and international point of view. In: Rodríguez Rodríguez, J.; Horsley, M.; Knudsen, S. V. 10th International Conference on Textbooks and Educational Media, IARTEM.

Braga Garcia, T. M., Schmidt, M. A. (2015). The Cultural Experience as a reference to the production of textbooks by teachers and children. In: Rodríguez Rodríguez, J.; Horsley, M.; Knudsen, S. V. 10th International Conference on Textbooks and Educational Media, IARTEM.

Bruillard, E., Villemonteix F. (2011). Les communautés en ligne d'enseignants, nouveaux modes d'organisation et de production. Mercredis de Créteil. Université Paris VIII.

Castiello, C. (2015). Libros de texto y materiales alternativos: La experiencia del grupo Eleuterio Quintanilla. In: Rodríguez Rodríguez, J.; Horsley, M.; Knudsen, S. V. 10th International Conference on Textbooks and Educational Media, IARTEM.

Choppin, A. (2003). Former les enseignants au choix et à leeutilisation de leurs manuels: histoire et actualité. In: Germain, B.; Le Guay, I. \& Nadine, R. (Eds.). Le Manuel de lecture au CP: réflexions, analyses et critères de choix (pp. 12-16). Paris: ScéREn, Savoir Livre.

Choppin, A. (2008). Le manuel scolaire, une fausse évidence historique. Revue d'Histoire de l'Éducation, INRP, n. 117, 19 juin 2008.

Cochran-Smith, M., Feiman-Nemser, S., McIntyre, D. J. \& Demers, K. E. (Eds.). (2008). Handbook of research on teacher education: Enduring questions in changing contexts. London: Routledge. 
Decreto Legislativo n. 297 del 16 aprile 1994, n. 297. Testo Unico delle disposizioni legislative vigenti in materia di istruzione, relative alle scuole di ogni ordine e grado (s.o. G.U. n. 115 del 19/5/1994). Available in: https:/www.miur.gov.it/documents/20182/21192/De creto+legislativo $+297+$ del $+1994 / 377 \mathrm{c} 571$ e-be98-44c6-8b19-8ff786f4c92b?version=1.0. Access in: Apr. 82019.

Decreto del Presidente della Repubblica n. 275 del 8 marzo 1999. Available in: https:// www.gazzettaufficiale.it/eli/id/1999/08/10/099G0339/sg. Access in: Apr. 82019.

Decreto Ministeriale n. 781 del 18 luglio 2017. Available in: https:/www.miur.gov.it/ web/guest/-/dd-n-781-del-18-7-2017. Access in: Apr. 82019.

Eco, U., Bonazzi, M. (1972). Introduzione a I pampini bugiardi. Indagine sui libri al di sopra di ogni sospetto: I testi delle scuole elementari. Rimini: Guaraldi.

Freinet, C. (1964). Plus de manuels scolaires! Plus de leçons! L'éducateur, November 1964.

Freinet, C. (2002). La scuola del fare. Parma: Edizioni Junior.

Freire, P. (2011). La pedagogia degli oppressi. Milano: Gruppo Abele. Tit. orig. Pedagogia do oprimido (1970).

Laici, C. \& Orlandini, L. (2016). Avanguardie Educative: paths of innovation for schools. Research on Education and Media, 8(1), 53-61.

Legge n. 517, del 4 agosto 1977. Available in: https://www.gazzettaufficiale.it/eli/ id/1977/08/18/077U0517/sg. Access in: Apr. 82019.

Legge n. 128, del 8 novembre 2013. Available in: https://www.gazzettaufficiale.it/eli/ id/2013/11/11/13G00172/sg. Access in: Apr. 82019.

Lodi, M. (1977). Perché no ai libri di testo, in "Cominciare dal bambino", Einaudi.

Mayring, P. (2014). Qualitative content analysis: theoretical foundation, basic procedures and software solution. Klagenfurt. URL: http://nbn-resolving.de/urn:nbn:de:0168-ssoar-395173.

Moeglin, P. (2010). Les industries éducatives, Que sais-je?, Paris: PUF.

Mortari, L. (Ed.). (2010). Dire la pratica: la cultura del fare scuola. Milano: Bruno Mondadori.

Munari, B. (2003). Da cosa nasce cosa. Roma-Bari: Laterza

Munari, B. (2004). Fantasia. Roma-Bari: Editori Laterza

Osberg, D., Biesta, G. (2008). The Emergent Curriculum: Navigating a Complex Course Between Unguided Learning and Planned Enculturation. Curriculum Studies, 40(3).

Pettini A. et al. (1969). Il libro di testo nella didattica moderna. Firenze: La Nuova Italia. 
Rodríguez Rodríguez, J., Garcia Garcia, I. (2015). The Electa Elemental Education Project. In: Rodríguez Rodríguez, J.; Horsley, M.; Knudsen, S. V. 10th International Conference on Textbooks and Educational Media, IARTEM.

Roncaglia, G. (2016). Ruolo ed evoluzione dei libri di testo. In: Reale, C. (Eds.). Il libro al centro. Percorsi tra le discipline del libro in onore di Marco Santoro. Napoli: Liguori.

Text received on $08 / 08 / 2019$. Text approved on 09/02/2019. 